\title{
A Thermodynamic Study of New Designed Complex of Ethylendiamine 8-Hydroxyquinolinato Palladium(II) Chloride with Calf Thymus DNA
}

\author{
M. Saeidfar, ${ }^{\S}$ H. Masouri-Torshizi, ${ }^{\S}$ G. Rezaei Behbehani, ${ }^{*}$ A. Divsalar, ${ }^{+,+}$and A. A. Saboury ${ }^{\star}$ \\ Chemistry department, Imam Khomeini International Lniversity, Qazvin. Iran. "E-mail: grb 402003 at vahoo.com \\ ${ }^{\dagger}$ Institute of Biochemistry and Biophisics. Uhiversity of Tehran. Tehran. Iran \\ 'Department of Biological Sciences, Tarbiat Hoallem University, Tehran, Iran \\ Chemistrv department, Lniversitu of Sistan \& Balluchestan, Zahedan. Iran \\ Received April 30, 2009, Accepted July 8, 2009
}

\begin{abstract}
A Thermodynamic study on the interaction of bovine calf thymus DNA with new designed Pd(II) complex (Ethylendiamine8-hydroxyquinolinato Palladium(II) chloride) was studied by using isothermal titration calorimetry (ITC) at $27^{\circ} \mathrm{C}$ in Tris buffer solution at $\mathrm{pH}=7.5$. The enthalpies of $\mathrm{Pd}(\mathrm{II})$ complex + DNA interaction are reported and analy sed in tenns of the new solvation theory. It was indicated that there are three identical and non-copperative sites for Pd(II) complex. The binding of a Pd(II) conplex is endothernic with association equilibrium constants of $428.03 \mathrm{mM}^{l}$ at $27^{\circ} \mathrm{C}$. The binding of $\mathrm{Pd}(\mathrm{II})$ complex can cause some changes in the stability of the DNA at low and high Pd(II) complex concentrations. Our results suggested that this complex might interact with DNA as an intercalator, thus interfering with DNA replication and cell proliferation.
\end{abstract}

Key Words: DNA, Pd(II) complex, Isothermal titration calorimetry

\section{Introduction}

DNA plays an important role in the life process. because it bears heritage information and instructs the biological synthesis of proteins and enzymes through the replication and transcription of genetic information in living cells. The main target of anti-tumor chemotherapies is DNA. ${ }^{1,2}$ Alteration of DNA stnicture affects its synthesis and function which usually leads to disruption of cell proliferation and can eventually elicit cell death $v i a$ apoptosis. These effects are currently being exploited to develop novel biologically active drugs with potential applications as anti-proliferative therapies. e.g. ligands that will form ternary complexes with DNA and the enzyme (s) topoisomerase. ${ }^{3: 5}$ Several experiments have also demonstrated that DNA is the primary intracellular target of anticancer drugs due to the interaction between small molecules and DNA, which can cause DNA damage in cancer cells. blocking the division of cancer cells and resulting in cell death. ${ }^{4-5}$ In addition, the apoptosis can also cause the cell death. ${ }^{3}$ The ability of small molecules to interfere with transcription and DNA replication makes it a major target for drug interaction studies.

Transition metal complexes have attracted considerable attention as catalytic systems for use in the oxidation of organic compounds ${ }^{8}$ probes in electron-transfer reactions involving metallo-proteins. and intercalators with DNA. ${ }^{3.9}$ During recent years, the interest for metal complexes containing planar extended polyaromatic ligands has increased tremendously. mainly for their usage as probes capable to utilize the nucleic acid stnictures ${ }^{1.2}$ and as DNA-molecular light switches. ${ }^{1.6}$ There are several types of sites in the DNA molecule where binding of metal complexes can occur: (I) between two base pairs (intercalation). (II) in the minor groove. (III) in the major groove. and (IV) on the outside of the helix. ${ }^{11}$

Among these complexes. the role of the Pt(II) and Pd(II) complexes is crucial since they can bind to DNA covalently as well as noncovalently. Several reports have shown that palladium complexes are expected to have lower kidney toxicity than cisplatin due to the inability of proteins in the kidney tubules to replace the tightly bound chelate ligands of Pd(II) with sulfydril groups. ${ }^{12-15}$ Concerning the noncovalent interactions between transition-metal complexes and DNA. they can occur by intercalation, groove binding or external electrostatic binding. ${ }^{1(-)] 1}$ Many anticancer drugs are known to interact with DNA to exert their biological activities. Generally. DNA-acting anticancer drugs can be classified into three categories. Drugs of the first category form covalent linkages with DNA while dnggs of the second category form noncovalent complexes with DNA by either intercalation or groove-binding. Drugs of the final category cause DNA backbone cleavages.

A search for new, low-molecular weight ligands which can specifically bind to DNA has been conducted for many years in the hope that new therapeutics could selectively modulate aberrant gene expression. ${ }^{1}$ Since design of new drugs that directly interacted with DNA is very important. in present study. we have investigated the effect of the new designed Pd(II) complex (Ethylendiamine 8-hydroxyquinolinato Palladium(II) chloride) (Scheme 1) on the stability of the calf thy mus DNA. in addition to some investigations on the binding parameters of complex to the DNA has been considered. Information obtained<smiles></smiles>

Scheme 1. The molecular structure of ethylendiamine 8-hydrosyquinolinato palladium(II) chloride (Pd(II) complex) 
Table 1. Enthalpies of Pd(II) complex + DNA interactions, Q, at $300 \mathrm{~K}$. Precision is $\pm 0.400 \mu \mathrm{J}$ or better

\begin{tabular}{ccll}
\hline$[$ Comp] $/ \mu \mathrm{M}$ & {$[\mathrm{DNA}] / \mu \mathrm{M}$} & $\mathrm{Q} / \mu \mathrm{J}$ & $\mathrm{Q}_{\text {dutut }} / \mathrm{\top}$ \\
\hline 9.12 & 119.57 & 12.415352 & 12.654532 \\
27.26 & 118.72 & 26.972077 & 28.189544 \\
45.27 & 117.88 & 41.85016 & 31.155128 \\
63.16 & 117.04 & 57.94362 & 33.266028 \\
80.91 & 116.21 & 75.381995 & 35.118395 \\
98.53 & 115.38 & 93.560856 & 36.950907 \\
116.02 & 114.56 & 112.81619 & 38.325542 \\
133.38 & 113.74 & 131.72873 & 39.449586 \\
150.61 & 112.93 & 151.46544 & 40.469381 \\
167.7 & 112.13 & 171.60718 & 41.464513 \\
184.67 & 111.33 & 191.72924 & 41.63489 \\
201.51 & 110.54 & 211.51649 & 41.078532 \\
218.22 & 109.75 & 232.22287 & 40.544077 \\
234.8 & 108.97 & 251.88747 & 41.532564 \\
251.24 & 108.19 & 271.58906 & 41.243349 \\
267.56 & 107.42 & 291.01553 & 39.283598 \\
283.74 & 106.65 & 310.73163 & 38.883865 \\
299.8 & 105.89 & 329.45623 & 38.391126 \\
315.73 & 105.14 & 347.97058 & 37.755725 \\
331.52 & 104.38 & 367.03017 & 37.065105 \\
347.18 & 103.64 & 385.46936 & 36.398395 \\
362.72 & 102.9 & 403.54151 & 35.797562 \\
378.12 & 102.16 & 421.72952 & 35.642693 \\
393.39 & 101.43 & 439.89584 & 34.82776 \\
408.54 & 100.7 & 457.01633 & 33.951757 \\
\hline 423.55 & 99.98 & 474.5883 & 33.888054 \\
\hline
\end{tabular}

from these studies will be helpful to understand the mechanisms of the interaction between the metal anticancer complexes and nucleic acids.

\section{Materials and Method}

Calf thymus DNA was obtained from Sigma. For the synthesis of ethylenediamine-8-hydroxy quinolinatopalladium(II) chloride. $\mathrm{Pd}(\mathrm{II})$ complex (Scheme 1), material required: 8hydroxyquinolin ethylenediamine, potassium tetrachloropalladate(II). sodium bicarbonate and sodium clloride were purchased from Aldrich (U. K). The first stage in this synthesis is the preparation of ethylenediamine palladium(II) dichloride $\left[\mathrm{Pd}(\mathrm{en}) \mathrm{Cl}_{2}\right]$. from which the titled compound is obtained. Place $1.63 \mathrm{~g}$ (mmol) $\mathrm{K}_{-} \mathrm{PdCl}_{4}$ in a $250 \mathrm{~mL}$ flask containing $200 \mathrm{~mL}$ distilled water and stirred for $10 \sim 15 \mathrm{~min}$ at $0^{\circ} \mathrm{C}$ in an ice bath. $99 \%$ ethylenediamine $(0.34 \mathrm{~mL} .5 \mathrm{mmol})$ was added dropwise while stirring vigorously. Stirring continued for another $2 \mathrm{~h}$ at room temperature. The crude yellowish brown precipitate so obtained was filtered and washed several times with water. ethyl alcohol and diethyl ether and dried at $40^{\circ} \mathrm{C}$. Yield was $1.05 \mathrm{~g}(89 \%)$. To obtain the titled compound from the chloride. a well suspension of [Pd(en) $\left.\mathrm{Cl}_{2}\right](0.237 \mathrm{~g} .1 \mathrm{mmol})$ in $20 \mathrm{~mL}$ water was treated with a solution of $\mathrm{NaHCO}_{3}(0.08+\mathrm{g}, 1 \mathrm{mmol})$ and 8-hỵdroxyquinoline $(0.1+5 \mathrm{~g} .1 \mathrm{mmol})$ in $20 \mathrm{~mL}$ water. The mixture was stirred at $45-50{ }^{\circ} \mathrm{C}$ for $2 \mathrm{~h}$. The yellow obtained solution was filtered and evaporated at $45-50^{\circ} \mathrm{C}$ to complete dryness. Recrýstallization was carried out by stirring the crude precipitate in $20 \mathrm{~nL}$ methanol-acetonitryl $(1: 1 \mathrm{v} / \mathrm{v})$ mixture and filtering out the undissolved particles. Diffusion of diethyl-ether into this filtrate gave yellow needle-like crystals. which were filtered off, washed with diethyl-ether, and dried in an oven at $45 \sim 50^{\circ} \mathrm{C}$. Yield: $0.242 \mathrm{~g}(78 \%)$. Anal calcd for $\mathrm{C}_{11} \mathrm{H}_{14} \mathrm{~N}_{3} \mathrm{O}$ Pd (310): $\mathrm{C}, 42.58 ; \mathrm{H}, 4.52$ : N. $13.55 \%$. Found: $\mathrm{C}$, 42.59: H. 4.50: N. 13.51\%. Solid state FT-IR spectroscopy of the above complex shows four characteristic bands at 1110 . 3071,3209 , and $341+\mathrm{cm}^{.1}$ assigned to $v^{\prime}(\mathrm{C}-\mathrm{O}$ stretching). $\mathrm{v}$ ( $\mathrm{C}-\mathrm{H}$ aromatic). v ( $\mathrm{C}-\mathrm{H}$ aliphatic) and $(\mathrm{N}-\mathrm{H}$ stretching) modes respectively. ${ }^{l} \mathrm{H}$ NMR ( $500 \mathrm{MHz}$. DMSO- $d$. ppm): protons of ethylenediamine moiety resonate at $2.6\left(\mathrm{~s}, 4 \mathrm{H}_{2} \mathrm{C}_{2} \mathrm{H}_{4}\right), 5.6$ $\left(\mathrm{s}, 2 \mathrm{H} . \mathrm{NH}_{2}\right)$. and $5.8\left(\mathrm{~s} .2 \mathrm{H}\right.$. $\mathrm{NH}_{2}$ ) and the protons of quinoline moiety resonate at 6.8 (doublet). 7.07 (doublet). 7.42 (triplet). 7.60 (quarter). 8.38 (doublet) and 8.56 (doublet). Electronic absorption spectrum of the Pd(II) complex shows two bands at 260 and $375 \mathrm{~mm}$ which are tentatively be assigned to the transition of $\mathrm{n} \rightarrow \hat{o}^{*}$ of phenolic $\mathrm{C}-\mathrm{O}$ and $\pi \rightarrow \pi^{*}$ of $\mathrm{C}=\mathrm{N}$ aromatic ring respectively:

The buffer solution used in the experiments was $50 \mathrm{mM}$ Tris. $\mathrm{pH}=7.5$. which was obtained from Merck. All other materials and reagents were of analytical grade.

The isothermal titration calorimetric experiments were carried out on a VP-ITC ultra sensitive titration calorimeter (MicroCal. LLC. Northampton. MA). The nicrocalorimeter consists of a reference cell and a sample cell of $1.8 \mathrm{~mL}$ in volume. with both cells insulated by an adiabatic shield. All solutions were thorougliy degassed before use by stirring under vacuum. The sample cell was loaded with DNA solution ( $120 \mu \mathrm{M})$ and the reference cell contained buffer solution. The solution in the cell was stirred at $307 \mathrm{rpm}$ by the sy ringe (equipped with nicro propeller) filled with $P d$ solution ( $2 \mathrm{mM}$ ) to ensure rapid mixing. Injections were started after baseline stability had been achieved. The titration of DNA with Pd solution involved 30 consecutive injections of the ligand solution. the first injection was $5 \mu \mathrm{L}$ and the remaining ones were $10 \mu \mathrm{L}$. In all cases. each injection was done in $6 \mathrm{~s}$ at 3 -min intervals. To correct the thermal effects due to $\mathrm{Pd}$ dilution control experiments were done in which identical aliquots were injected into the buffer solution with the exception of DNA. In the ITC experiments, the enthalpy changes associated with processes occurring at a constant temperature are measured. The measurements were performed at a constant temperature of $27.0 \pm 0.02{ }^{\circ} \mathrm{C}$ and the temperature was controlled using a Poly-Science water bath.

\section{Results and Discussion}

It has been shown previously $y^{16-26}$ that the enthalpies of interactions of biopoly mers with ligands (DNA + Pd(II) complex in this case) in the aqueous solvent (Pd(II) complex + water in the present case) mixtures. can be reproduced via the following equation

$$
\begin{aligned}
Q & =Q_{\max } x_{B}^{\prime}-\delta_{-i}^{\dot{\theta}}\left(x_{.4}^{\prime} L_{-4}+x_{B}^{\prime} L_{B}\right) \\
& -\left(\delta_{B}^{\theta}-\delta_{A}^{\theta}\right)\left(x_{. A}^{\prime} L_{.4}+x_{B}^{\prime} L_{B}\right) x_{B}^{\prime}
\end{aligned}
$$

The parameters $\delta_{t}^{*}$ and $\delta_{b}^{\theta}$ are the indexes of the DNA sta- 


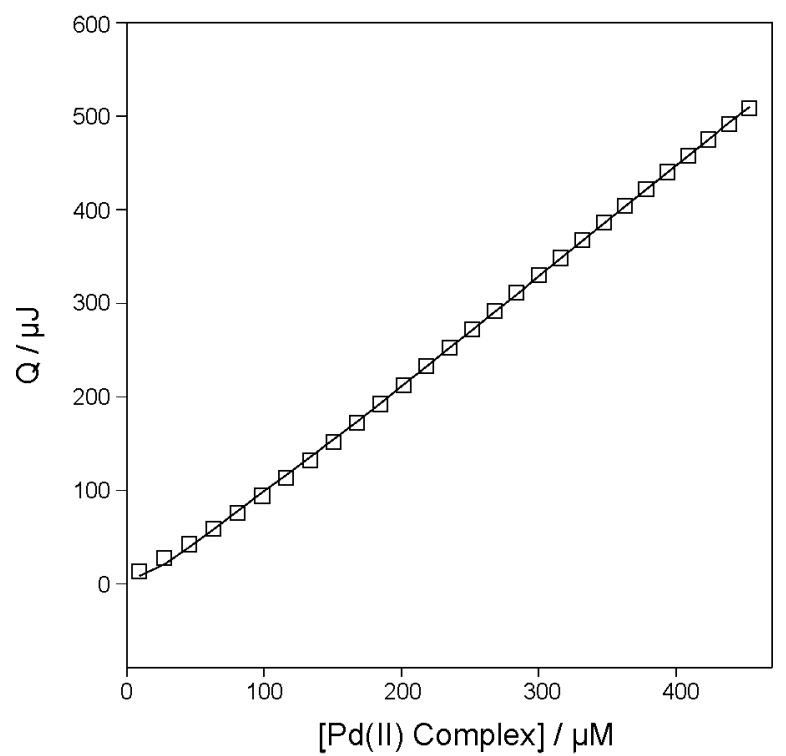

Figure 1. Comparison between the experimental enthalpies for $\mathrm{Pd}$ (II) complex + DNA interactions at $300 \mathrm{~K}$ and calculated data (lines) via equation 1 .

Table 2. Binding parameters for PdiII) complex + DNA interactions via equations 1 and $15 . p=1$ shows the overall non-cooperativity for the interaction of $\mathrm{Pd}(\mathrm{II})$ complex with DNA. The big association equilibrim constant values show that there is strong interaction between Pd(II) complex and DNA

\begin{tabular}{cc}
\hline parameters & $\mathrm{T}=300 \mathrm{~K}$ \\
\hline$K_{1} / \mathrm{mM}^{-1}$ & $428.03 \pm 0.02$ \\
$K_{2} / \mathrm{mM}^{-1}$ & $428.03 \pm 0.02$ \\
$K_{3} / \mathrm{mM}^{-1}$ & $428.03 \pm 0.02$ \\
$p$ & $1.000 \pm 0.002$ \\
$\delta_{A}^{\theta}$ & $0.615 \pm 0.077$ \\
$\delta_{\Xi}^{\theta}$ & $0.849 \pm 0.052$ \\
$\Delta H_{\max } / \mathrm{kJ}^{-1 m o l} l^{-1}$ & $1.481 \pm 0.034$ \\
\hline
\end{tabular}

bility as a result of interaction with $\mathrm{Pd}(\mathrm{II})$ complex in the low and high $\mathrm{Pd}(\mathrm{II})$ complex concentrations respectively. Cooperative binding requires that the macromolecule have more than one binding site. since cooperativity results from the interactions of identical binding sites with some similar ligands. If the binding of ligand at one site increases the affunity for ligand at another site. the macromolecule exlibits positive cooperativity. Conversely, if the binding of ligand at one site lowers the affinity for ligand at another site. the protein exhibits negative cooperativity. If the ligand binds at each site independently. the binding is non-cooperative. $x_{B}^{\prime}$ can be expressed as follows:

$$
x_{B}^{\prime}=\frac{p x_{B}}{x_{i}+p x_{B}}
$$

$p<\mathrm{I}$ or $p>\mathrm{I}$ indicate positive or negative cooperativity of macromolecule for binding with ligand respectively: $p=1$ indicates that the binding is non-cooperative. $x_{B}$ is the fraction of bounded Pd(II) complex with DNA, and $x_{A}=1-x_{B}$ is the fraction of unbounded $\mathrm{Pd}(\mathrm{II})$ complex. We can express $x_{B}$ frac- tions, as the total $\mathrm{Pd}(\mathrm{II})$ conplex concentrations divided by the maximum concentration of the $\mathrm{Pd}(\mathrm{II})$ complex upon saturation of all DNA as follows:

$$
x_{B}=\frac{[P d(I) \text { complex }]_{T}}{[P d(I I) \text { complex }]_{\max }} x_{-1}=1-x_{B}
$$

$[\mathrm{Pd}(\mathrm{II}) \text { complex }]_{\mathrm{T}}$ is the total concentration of the $\mathrm{Pd}(\mathrm{II})$ complex and $[\mathrm{Pd}(\mathrm{II}) \text { complex }]_{\max }$ is the maximum concentration of the Pd(II) complex upon saturation of all DNA. $L_{t}$ and $L_{B}$ are the relative contributions of unbounded and bounded $\mathrm{Pd}(\mathrm{II})$ complex to the enthalpies of dilution with the exclusion of DNA and can be calculated from the enthalpies of dilution of $\mathrm{Pd}(\mathrm{II})$ complex in buffer as follows:

$$
L_{A}=Q_{\text {dihlt }}+x_{B}\left(\frac{\partial Q_{\text {iilkt }}}{\partial x_{B}}\right), L_{B}=Q_{\text {dithet }}-x_{A}\left(\frac{\partial Q_{\text {dikt }}}{\partial x_{B}}\right)
$$

The enthalpies of $\mathrm{Pd}(\mathrm{II})$ contex $+\mathrm{DNA}$ interactions. $Q$, were fitted to Eq. lover the whole $\mathrm{Pd}(\mathrm{II})$ complex compositions. In the fitting procedure, $p$ parameter varied in the course of an iterative process until the best fit between experimental and calculated data was approached (Fig. 1). $\delta_{A}^{*}$ and $\delta_{B}^{\theta}$ parameters have been also optimized to fit the data. The optimized $\delta_{4}^{*}$ and $\delta_{B}^{*}$ values are recovered from the coefficients of the second and third termus of $\mathrm{Eq}$. 1 . The small relative standard coefficient errors and the high $r^{2}$ values (0.99999) support the method. The binding parameters for $\mathrm{Pd}$ (II) complex + DNA interactions recovered from $\mathrm{Eq}$. 1 were listed in Table 2. The agreement between the calculated and experimental results (Fig. l) is striking, and gives considerable support to the use of Eq. I. $\Phi$ is the fraction of DNA molecule undergoing complexation with Pd(II) complex which can be expressed as follows:

$$
\Phi=\frac{Q}{Q_{\operatorname{tax}}}
$$

$Q_{\max }$ represents the heat value upon saturation of all DNA. The appearance equilibrium constant values, $K_{*}$, as a function of free concentration of $\mathrm{Pd}$ (II) complex. [Pd(II) complex] $]_{\mathrm{F}}$ can be calculated as follows:

$$
\begin{aligned}
K_{a} & =\frac{\Phi}{(1-\Phi)[P d(I I) \text { complex }]_{F}} \\
& =\frac{\Phi}{(1-\Phi)[\text { Pd(II)complex }]_{T}\left(1-x_{B}\right)}
\end{aligned}
$$

The Gibbs free energies as a function of Pd(II) complex concentrations can be obtained as follows:

$$
\Delta G=-R T L n K_{a}
$$

Gibbs energies. $\Delta G$. at different temperatures calculated from Eq. 7 have shown graplically in Fig. 2. $\Delta S$ Svalues were calculated using $\Delta G$ values at different temperatures and have shown in Fig. 3. 


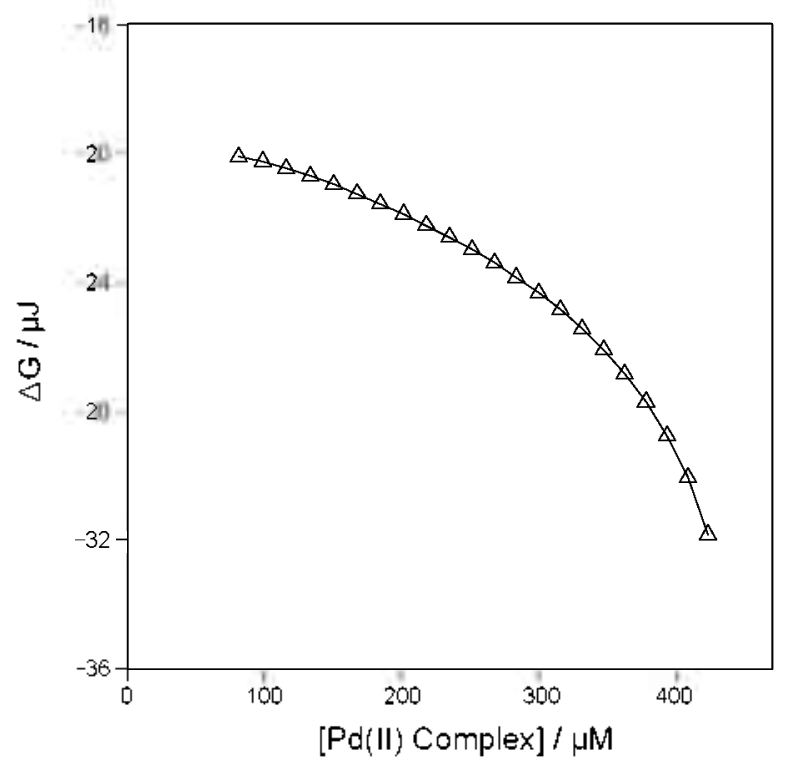

Figure 2. Comparison between the experinental Gibbs free energies at $300 \mathrm{~K}$ for Pd(II) complex + DNA interactions and calculated data (lines) via equation 7 . The linearity of $\Delta G$ against PdiII) complex concentrations indicates that the structural effects compensate each other in the free energy with support the solvation model.

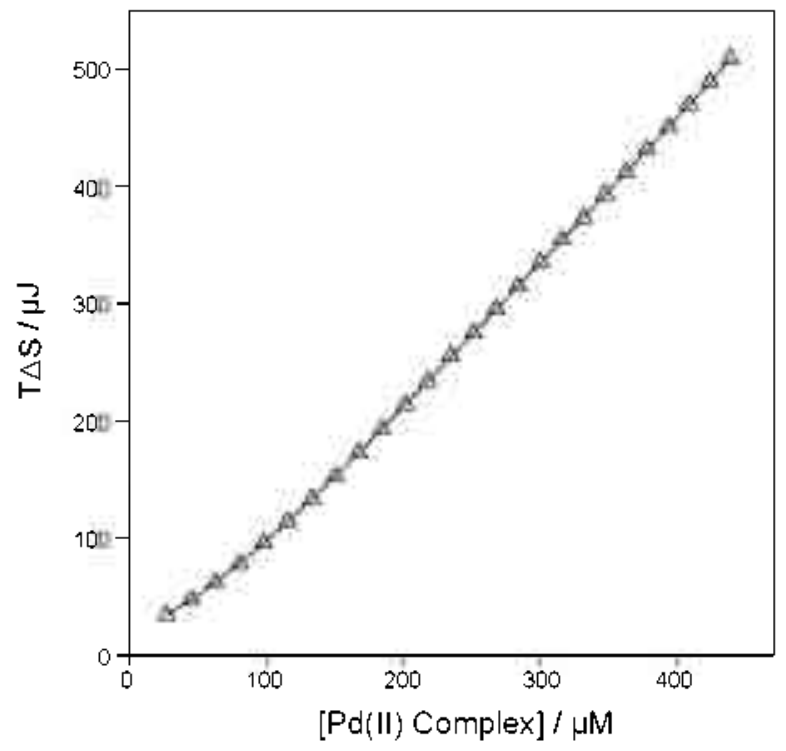

Figure 3. Comparison between the experinental entropies at $300 \mathrm{~K}$ for Pd(II) complex + DNA interactions in and calculated data (lines) via equations 1 and 7.

Consider a solution containing a ligand (Pd(II) complex) and a macromolecule $\left(\mathrm{DNA}_{\mathrm{g}}\right.$ ) that contains " $g$ " sites capable of binding the ligand. If the multiple binding sites on a macromolecule are identical and independent. the ligand binding sites can be reproduced by a model system of monovalent molecules $\left(D N A_{g} \rightarrow g D N A\right.$ ) with the same set of dissociation equilibrium constant. $K_{d}$, values. Thus. the reaction under consideration can be written:

$$
M+L \Leftrightarrow M / L K_{d}=\frac{[M /[L]}{[M / L]}
$$

If $\alpha$ is defined as the fraction of free binding sites on the biomacromolecule, $M_{i}$ is the total biomacromolecule concentration. and $L_{0}$ is the total ligand concentration. then the free concentrations of monovalent molecule $[M]$ and ligand $[L]$ as well as the concentration of bound ligand $[M L]$ can be deduced as follows

$$
\begin{aligned}
& {[M L]=g(1-\alpha) M_{0}} \\
& {[L]=L_{\imath}-[H L]=L_{0}-g(1-\alpha) H_{0}} \\
& {[M]=g H_{0}-[M L]=g H_{0}-g(1-\alpha) M_{0}=\alpha g M_{0}}
\end{aligned}
$$

Substitution of free concentrations of all these components in Eq. 8 gives:

$$
\begin{aligned}
& K_{d}=\left(\frac{\alpha}{1-\alpha}\right) L_{0}-\alpha g H_{0} \\
& \alpha M_{0}=\left(\frac{\alpha}{1-\alpha}\right) \frac{1}{g} L_{0}-\frac{K_{d}}{g}
\end{aligned}
$$

The value of $l-\alpha$ as the fraction of occupied binding sites on the biomacromolecule:

$$
1-\alpha=\frac{Q}{Q_{\max }}
$$

where $q$ represents the heat value at a certain $L_{i}$ and $Q_{\max }$ represents the heat value upon saturation of all biomacromolecules. The combination of Eqs. 13 and 14 yields:

$$
\frac{\Delta Q}{Q_{\max }} M_{0}=\left(\frac{\Delta Q}{Q}\right) L_{0} \frac{1}{g}-\frac{K_{d}}{g}
$$

Where $\Delta Q=Q_{\max }-Q$ Therefore, the plot of $\frac{\Delta Q}{Q_{\max }} M_{0}$ versus $\frac{\Delta Q}{Q} L_{0}$ should be a linear plot with a slope of $\frac{\bar{I}}{g}$ and a verticalintercept of $\frac{\pi_{i+}}{g}$.

The linearity of the plot has been examined by different estimated values for $Q_{\max }$ to reach the best value for the correlation coefficient. The best linear plot with the correlation coefficient value $\left(r^{2} \approx 1\right.$ ) was obtained using $320 \mu \mathrm{J}$ (equal to 1.481 $\mathrm{kJ} / \mathrm{mol}$ ). The values of $g$ and $K_{d}$ obtained from the slope and vertical-intercept plot, are listed in Table 2. The calorimetric method described recently allows obtaining the number of binding sites (g), the molar enthalpy of binding site $\left(\Delta H_{b i n}=\frac{Q_{\max }}{g}\right)$ and the dissociation equilibrium constant $\left(K_{d}\right)$ for a set of biomacromolecule binding sites. The lack of a suitable value for $Q_{\text {min }}$ to obtain a linear plot of $\left(\Delta Q / Q_{\max }\right) M_{0} v s .(\Delta Q / Q) L_{1}$ may be related to the existence of non-identical binding sites or the interaction between them. Using this method shows that there is a set of three identical and non-interacting binding sites for Pd(II) complex. Binding parameters for Pd(II) complex + DNA inter actions using the new model are listed in Table 2. 
The positive value for $\delta_{. t}^{\theta}(0.616)$ in the low concentration of $\mathrm{Pd}(\mathrm{II})$ Complex, indicates that DNA structure is stabilized as a result of binding to $\mathrm{Pd}(\mathrm{II})$ Complex. The more positive value of $\delta_{g}^{\theta}(0.8+9)$ reflects stabilization of the calf thymus DNA structure in the high concentration of Pd(II) complex too. In other words. the positive values of $\delta_{z}^{\theta}$ suggest that complex binds preferentially to the native state of DNA. $p$ value $(p=1)$ shows the overall non-cooperativity for the interaction of Pd(II) complex with DNA including both specific and non-specific interactions. Hossain and Huq" have studied the interactions between Pd(II) conplex ions and DNA and they believed that $\mathrm{Pd}(\mathrm{II})$ complex covalently bind into adenine and guanine in DNA. The big association equilibrium constant values $\left(\mathrm{K}_{4}=\right.$ $428.03 \pm 0.02 \mathrm{mM}^{-1}$ ) show that there is strong interaction between Pd(II) complex and DNA. which is in agreement with the above interpretation. Also. other reports have revealed that small organic compounds and transition metal complexes could bind noncovalently (including as intercalators and groove binders) to nucleic acids. These interactions have been shown to disnupt the replication and/or transcription culminating in a cellular death. ${ }^{37}$ Lntercalators. by definition, bind into DNA by intercalating the flat aromatic ring between the base pairs of the DNA duplex ${ }^{28}$ An intercalator makes contact with two base-pairs whereas a groove binder can span many more. making interactions with several reactive sites along DNA grooves. e.g. phosphate groups. electron acceptors and donors. hydrophobic sites. and acidic hydrogen ' $\mathrm{s}$. Since the new synthesized Pd(II) complex is a planar system, then, the planar moieties of this complex might be inserted between the DNA base-pairs. parallel to their aromatic rings and perpendicular to the helical axis. As a consequence. this complex might interact with DNA as an intercalator, thus interfering with DNA replication and cell proliferation.

\section{Conclusion}

The enthalpies of Pd(II) complex + DNA interaction were fitted to Eq. lover the whole Pd(II) complex compositions. In the procedure the only adjustable parameter $(p)$ was changed until the best agreenent between the experimental and calculated data was approached (Fig. 1). The optimized $\delta_{A}^{\theta}$ and $\partial_{B}^{\theta}$ values are recovered from the coefficients of the second and third terms of Eq. 1. The agreement between the calculated and experimental results (Fig. 1) is striking. and gives considerable support to the use of $\mathrm{Eq} .1 . p=1$ indicates that the binding of $\mathrm{Pd}(\mathrm{II})$ complex with DNA is non-cooperative. A suitable value for $Q_{\max }$ to obtain a linear plot of $\left(\Delta Q / Q_{\max }\right) M_{i} v s .(\Delta Q / Q) L_{c}$ indicates that there are a set of three identical and non-interacting binding sites on DNA for $\mathrm{Pd}(\mathrm{II})$ complex.

\section{References}

1. Bajdichova, M.; Busa, J.; Podhradsky, D.; Imrich, J. Int. J. Biol. Hacromol $2007,+1,415$.

2. Lemke, K.; Wojciechowski, M.; Laine, W: Bailly, C.; Colson, P.; Baginski, M.; Larsen, A.: Skladanowski, A. Mucl. Acids. Res. $2005,33,6034$.

3. Perez-Flores, L.: Ruiz-Chica, A. I.: Delcros, J. G.; Súnchez-Iiméne, F. M.: Ramirez, F. J. Spectrochm. Acta. Part 1 2008, 69, 1089.

4. Larsen, A. K.; Escargueil, A. E.; Skladanowski, A. Phamacol. Ther: 2003, 99, 167.

5. Marco, E.; Laine, W.; Tardy, C.; Lansiaux, E; Iwao, M.; Ishibashi, F; Bailly, C.; Gago, F. J. Med. Chem. 2005, 48, 3796.

6. Fox, K. R.; Harrison, N. K.: Waring, M. I. FEBS Lett. 1981, 133, 305 .

7. Metcalfe, C.: Thomas, J. A. Chem. Soc. Rev 2003, 32, 215.

8. Graves, D. E.: Velea, L. M. Cum. Ong. Chem. $2000,4,915$.

9. McDonald, L. A.; Eldredge, G. S.; Barrows, L. R.; Ireland, C. M. J. Hed. Chem. 1994, 37, 3819.

10. Mandal, S.; Lloret, F; Mukherjee, R. Inorg. Chim. Acta 2008, 362,27

11. Arounaguir, S.: Maiya, B. G. Inorg. Chem. 1999, 38,842 .

12. Divsalar, A.: Saboury, A. A:; Yousefi, R.: Moosavi-Movahedi, A. A.: Mansoor-Torshizi, H. Int. J. Biol Macromol 2007, $+(0,381$.

13. Divsalar, A.; Saboury, A. A: Moosavi-Movahedi, A. A.: MensoorTorshizi, H. J. Bionol. Struct. Dyn. 2007, 25, 1

14. Mansouri-Torshizi, H.; I-Moghaddam, M:; Divsalar, A.; Saboury, A. A Bioorg. Med. Chem. 2008, 16, 9616.

15. Mansouri-Torshizi, H.; I-Moghaddam, M.; Saboury, A. A. Acta Biochim. Biophss. Si. 2003, 35, 886 .

16. Saboury, A. A.J. Them Anal Cal 2003, 72, 93.

17. Rezalei Belibehani, G.; Ghamany, S.: Waghome, W. E. Themochim. Acta 2006, $4+8,37$.

18. Rezaei Behbehani, G.; Tazikeh E:- Saboury, A. A. Acta Chim. Slov: $2006,53,363$.

19. Rezaei Behbehani, G.; Saboury, A. A. Thermochim . Acta 2007, 452,76 .

20. Rezaei Behthehani, G.; Saboury, A. A: Fallah baghery, A J. Solution Chem. 2007, 36, 1311.

21. Rezaei Behbehani, G.; Saboury, A. A.: Táleshi, E. J. Solution Chem. 2008, 37, 619 .

22. Rezaei Behbehani, G.; Saboury, A. A. J. Therm. Anal Calorm. 2007, 89, 859.

23. Rezaei Behbehani, G.; Saboury, A. A.; Takeshi, E. J. Hol. Recognit. $2008,21,132$.

24. Rezaei Behbehani, G.: Saboury, A A. J. Coll Shrf. B: Bionterfaces 2007, 61, 224.

25. Rezaei Belhbehani, G.: Divalar, A : Bagheri, M J.: Saboury, A. A. J. Solution Chem. 2008, 37, 1785 .

26. Rezaei Behbehani, G.; Divsalar, A.; Saboury, A. A.; Gheibi, N. J. Solution Chen. 2008, 37, 1645.

27. Hossain, Z.; Huq, F. J. Inorg. Biochem. 2002, 90, 85. 